\title{
In Vitro and Ex Vivo Analysis of Collagen Foams for Soft and Hard Tissue Regeneration
}

\author{
OLE JUNG ${ }^{1}$, MIKE BARBECK ${ }^{2,3}$, LU FAN $^{4}$, FABIAN KORTE $^{4}$, CUIFENG ZHAO ${ }^{5}$, \\ RUMEN KRASTEV ${ }^{4,5}$, SVEN PANTERMEHL $^{1 *}$ and XIN XIONG ${ }^{2 *}$ \\ ${ }^{1}$ Clinic and Policlinic for Dermatology and Venereology, University Medical Center Rostock, Rostock, Germany; \\ ${ }^{2}$ BerlinAnalytix GmbH, Berlin, Germany; \\ ${ }^{3}$ Department of Ceramic Materials, Chair of Advanced Ceramic Materials, \\ Institute for Materials Science and Technologies, Technical University Berlin, Berlin, Germany; \\ ${ }^{4}$ NMI Natural and Medical Sciences Institute at the University of Tübingen, Reutlingen, Germany; \\ ${ }^{5}$ Faculty of Applied Chemistry, Reutlingen University, Reutlingen, Germany
}

\begin{abstract}
Background/Aim: The aim of this study was the conception, production, material analysis and cytocompatibility analysis of a new collagen foam for medical applications. Materials and Methods: After the innovative production of various collagen sponges from bovine sources, the foams were analyzed ex vivo in terms of their structure (including pore size) and in vitro in terms of cytocompatibility according to EN ISO 10993-5/-12. In vitro, the collagen foams were compared with the established soft and hard tissue materials cerabone and Jason membrane (both botiss biomaterials GmbH, Zossen, Germany). Results: Collagen foams with different compositions were successfully produced from bovine sources. Ex vivo, the foams showed a stable and long-lasting primary structure quality with a bubble area of 1,000 to 2,000 $\mathrm{mm}^{2}$. In vitro, all foams showed sufficient cytocompatibility. Conclusion: Collagen sponges represent a promising material for hard and soft tissue regeneration. Future studies could focus on integrating and investigating different additives in the foams.
\end{abstract}

Collagen is the most abundant protein in the human body and constitutes around $25-30 \%$ of the total amount of protein $(1,2)$. Up to now, 28 different types of collagen have been

This article is freely accessible online.

*These Authors contributed equally to this study.

Correspondence to: Dr. Xin Xiong, NMI Natural and Medical Sciences Institute at the University of Tübingen, Reutlingen, Germany. Tel: +49 712151530413, e-mail: xin.xiong@nmi.de

Key Words: Collagen, collagen foam, tissue regeneration, macrophages, vascularization, soft tissue, hard tissue. discovered (3). As an essential part of the extracellular matrix (ECM), different collagen types can be found in bones, cartilage, tendons and skin, as well as in teeth, cornea and blood vessels (4-6). Collagen is biocompatible and completely biodegradable by endogenous human proteases $(7,8)$. In addition, it is characterized by its ability to positively influence cell adhesion, cell proliferation, and differentiation $(1,4,9)$. These qualities can be further increased by adding growth and differentiation factors to the collagen matrix $(10,11)$. Antibacterial properties can be developed by adding nanoparticles such as $\operatorname{AgNP}(12,13)$. By additional physical as well as chemical cross-linking (68,14 ) or the combination of different types of collagen with and without additional bioabsorbable materials, the usually short-lasting degradation time of natural collagen can be further extended, which ensures a sufficient durability (e.g., in wound dressings) $(15,16)$.

These properties make collagen as one of the most promising biomaterials in modern medicine. Depending on the area of application, it is obtained autogenously, allogenically or xenogenically $(17,18)$. Collagen is widely used as a wound dressing in the treatment of acute or chronic wounds (19), burn wounds $(20,21)$ or sites of skin donation and skin grafts (22), through its ability of shielding the wound from infection and contamination, reducing scarring, absorbing wound exudate, and promoting the skin's natural regeneration ability $(19,23,24)$. In addition, collagen is able to bind platelets and thus activate the coagulation cascade $(25,26)$, which makes it very suitable for acute use in wound care. Resorbable barrier membranes made of collagen are of great importance in guided bone regeneration (GBR) for dentistry and oral and maxillofacial surgery, in order to shield the regenerating bone from the ingrowth of the surrounding tissue (27-29). Furthermore, different compositions of collagen can be used as tissue grafts in 


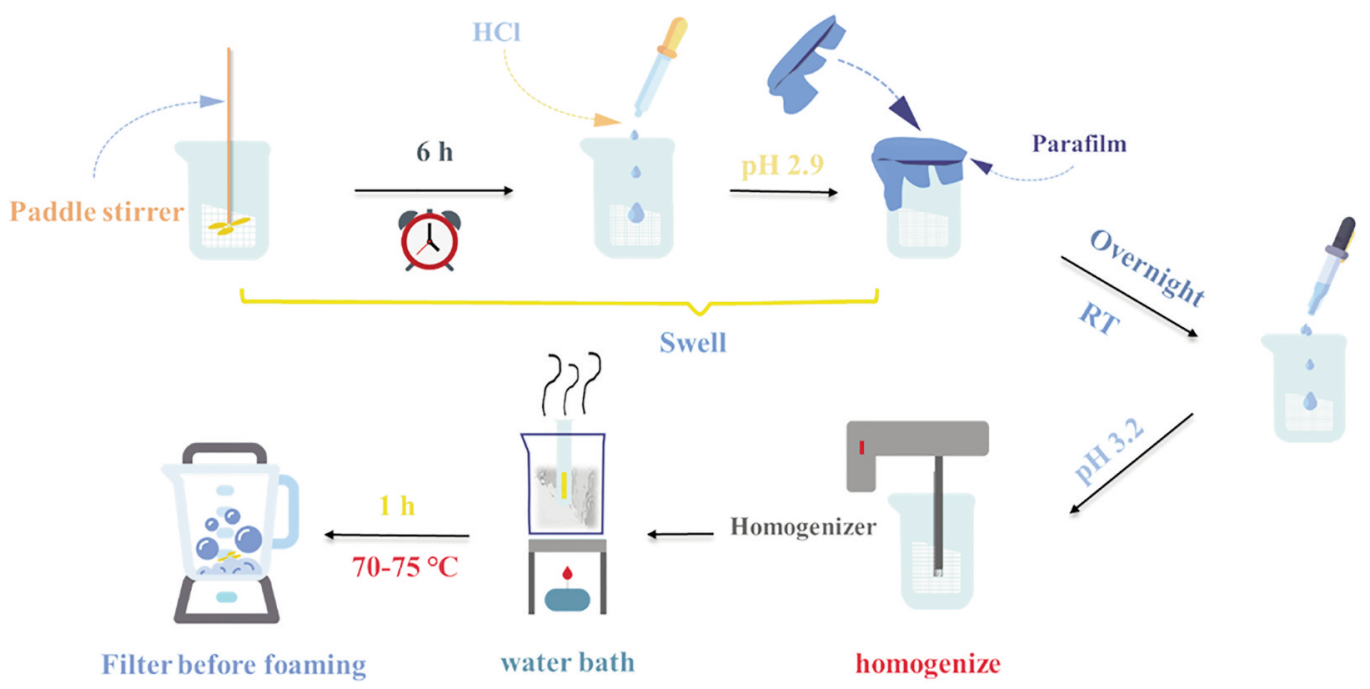

Figure 1. Processing of collagen foam.

peripheral nerve regeneration, vascular prostheses and arterial reconstruction (30-33). In addition, by promoting cell growth and adhesion, collagen is ideally suited as a substance in tissue engineering, where it can be used as part of bioinks to encapsulate cells $(34,35)$ or as basic substance for scaffold production $(2,22)$. Thereby, it is essential for the development of artificial skin implants $(36,37)$.

The present study aimed to develop a new collagen foam based on bovine split skin for tissue regeneration. The regeneration-promoting properties of collagen are extensively described in literature $(4,15,38)$. Especially for wound regeneration, collagen foams appear to be a promising approach, since a foam can optimally adapt to a wound bed in terms of area and volume and has both a shielding and cushioning effect on the tissue (19). The approach of using biomaterials as applicable foams in wound management has already been implemented in a different context. The wound foams that have been used up to now are primarily designed for the care of moist or weeping chronic wounds, as their base materials have good exudate-absorbing characteristics (19).

With the use of collagen and the creation of a moisturizing instead of a dehumidifying environment in the wound bed, the foam presented in this study aims to positively influence the self-healing of soft tissue by using the natural regenerative properties of this biomaterial. The newly developed collagenbased foam has the potential to be a new and innovative biomaterial for use in soft tissue regeneration and could play a major role in the care of patients with acute or chronic wounds.

The focus of this preclinical study was to analyze the material characteristics and cytocompatibility of different novel collagen foams. For this purpose, pore size, density and surface structure of the foams were examined and described ex vivo using a dynamic foam analyzer (DFA) and
cryo-SEM. In addition, in vitro cytocompatibility studies were carried out in accordance with ISO 10993-5/-12, as already described in previous work $(24,39,40)$.

\section{Materials and Methods}

Collagen foam preparation. For fabricating the collagen foam, bovine split skin was homogenized via serial mechanical treatment steps, as illustrated in Figure 1. Briefly, split skin was thawed at $4^{\circ} \mathrm{C}$. Then, the split skin was rinsed in double-deionized water $(\mathrm{ddH} 2 \mathrm{O})$ which was added at a ratio of $6.5: 1(\mathrm{w} / \mathrm{w})$ to the split skin. The split skin was then rinsed under agitation using a paddle mixer (IKA ${ }^{\circledR}$ Digital 20, IKA ${ }^{\circledR}$ Works, Inc., Wilmington, NC, USA) at $70 \mathrm{rpm}$ for $3 \mathrm{~h}$ and pre-homogenized at $720 \mathrm{rpm}$ for another $3 \mathrm{~h}$. The $\mathrm{pH}$ value was adjusted to 2.9 with HAc (acetic acid water solution). The suspension was stored at room temperature overnight before further processing. After adjusting the $\mathrm{pH}$ value to 3.2 , the split skin suspension was homogenized with an IKA ${ }^{\circledR}$ Ultra-Turrax homogenizer (IKA ${ }^{\circledR}$ Works, Inc.) (about 12,000 rpm) for $1 \mathrm{~min}$. The homogenization was then treated in a water bath at $75^{\circ}$ for $1 \mathrm{~h}$. The treated suspension was further diluted using $0.1 \%$ HAc at a ratio of $1: 1$ and filtered via a Buchner Funnel. The filtered suspension was then foamed using a foaming paddle to form liquid collagen foam. Foams with a final protein concentration ranging from 10 to $50 \mathrm{mg} / \mathrm{ml}$ were prepared.

Ex vivo analyses. Pore structure and foam characterization. For determination of the bubble size and size distribution of the collagen foams, a dynamic foam analyzer (DFA100, Krüss GmbH, Hamburg, Germany) equipped with a CCD-camera was applied. Size and amount of the bubble fractions were determined via the "bubbles' different projected area" method (Figures 2 and 3).

Cryo focus ion beam/Scanning electron microscopy (SEM). Collagen foams with a final concentration of $20 \mathrm{mg} / \mathrm{ml}$ were analyzed by cryo-SEM. Briefly, the sample was frozen in liquid nitrogen. Without removing the sample from the liquid nitrogen, it was mounted onto a cooled sample holder. The holder was 

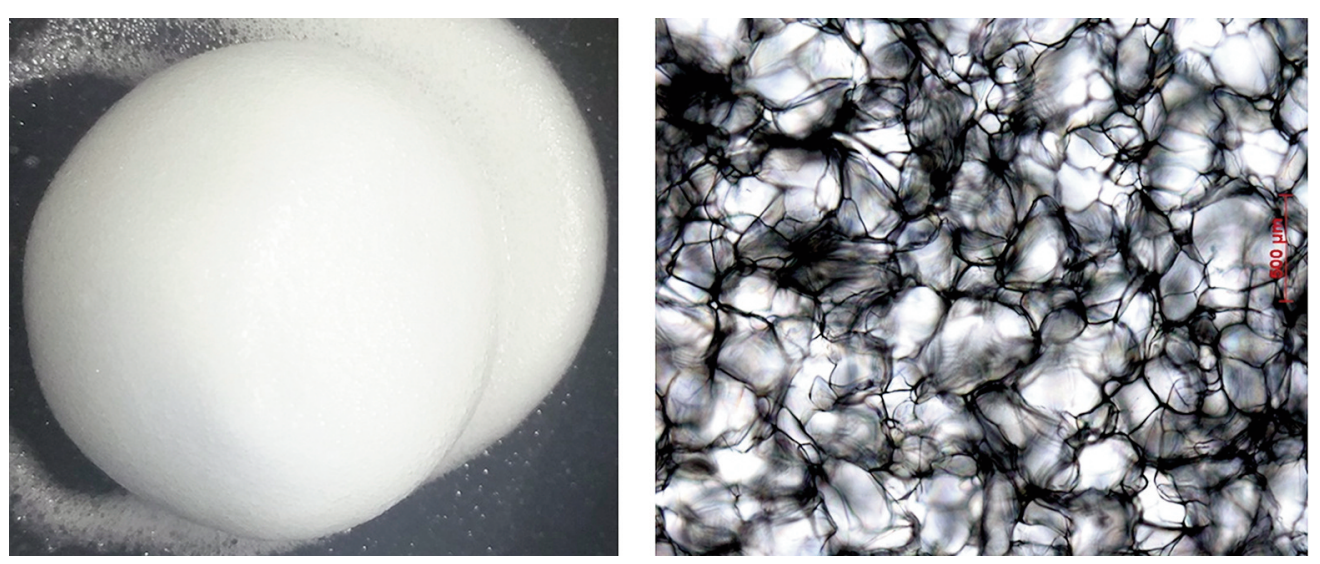

Figure 2. Macroscopic and microscopic imaging of the collagen foam. (A) Freshly prepared collagen foam. (B) Freeze dried foam for lightmicroscopic slides. As the foam was lyophilized, the pore size was not directly correlated to the pore size in foam.
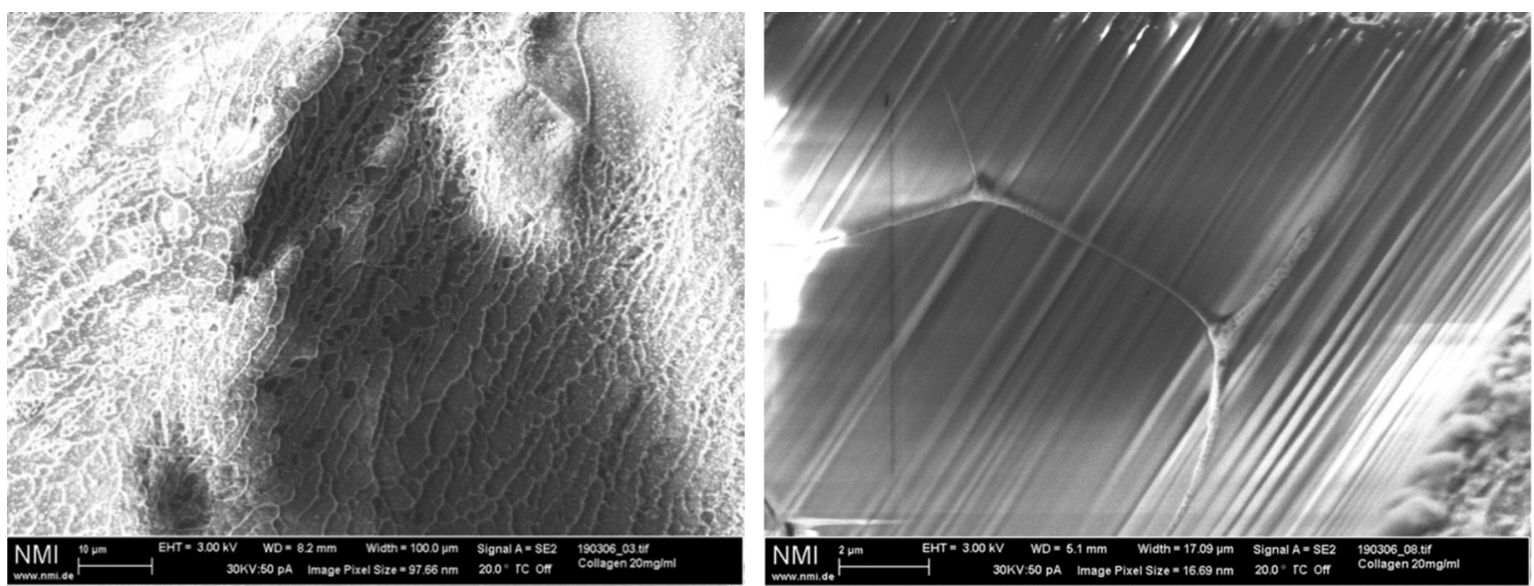

Figure 3. FIB-cryo-SEM imaging of the foam. (A) Image with a full width of $100 \mu \mathrm{m}$. The structure of the collagen foam can be observed. The bubbles were organized in an oriented structure during foam formation. (B) Image with a full length of $17.09 \mu m$. The bubble shown in the image has a diameter of about $14 \mu \mathrm{m}$ and the foam lamella can be observed clearly.

transferred into a vacuum shuttle (Leica EM VCT100, Leica Microsystems GmbH, Wetzlar, Hessen, Germany). After loading, the shuttle was connected immediately to a sputter coater (Balt-Tec SCD 500, Leica Biosystems Division of Leica Microsystems Inc., Buffalo Grove, IL, USA) and evacuated so that the sample could be transferred to the cryo stage of the electron microscope (Zeiss LEO 1540XB with cryo stage, Carl Zeiss Microscopy Deutschland $\mathrm{GmbH}$, Oberkochen, Baden-Württemberg, Germany). The sample was then imaged with the electron beam and the stage was heated until sublimation of the ice matrix could be observed, which occurred around $-100^{\circ} \mathrm{C}$. The sample was transferred after coating with about $10 \mathrm{~nm}$ of platinum. Using a focused ion beam, the cross section of the samples was prepared and imaged with SEM.

In vitro experiments. The cytocompatibility analysis was conducted according to the DIN EN ISO 10993-5: 2009/-12: 2012 regulations as previously published $(24,27,39)$. In brief, each of two collagen foam samples with final concentrations of $10 \mathrm{mg} / \mathrm{ml}$ or $30 \mathrm{mg} / \mathrm{ml}$ were used for the extract assays. The samples were extracted for $72 \pm 2 \mathrm{~h}$ in extraction medium at $37^{\circ} \mathrm{C}, 5 \% \mathrm{CO}_{2}$ and $95 \%$ humidity. The extraction medium was then transferred to L-929 mouse fibroblasts, purchased from the European Collection of Cell Cultures, ECACC (Salisbury, UK) and incubated with the cells at standard cell culture conditions; $37^{\circ} \mathrm{C}, 5 \% \mathrm{CO}_{2}$ and $95 \%$ humidity for $24 \mathrm{~h}$. Viability, proliferation and cytotoxicity determinations were carried out using the XTT assay (Roche Diagnostics, Mannheim, Germany), BrdU ELISA (Roche Diagnostics) and LDH assay (BioVision, Milpitas, CA, USA) in four determinations for each test sample. As comparative materials with expectable biocompatibility, Jason ${ }^{\circledR}$ membrane and Cerabone $^{\circledR}$ (both from botiss biomaterials GmbH, Zossen, Germany) were used for additional extract assays and examined under the same conditions, as already described above. Blank values (only medium without cells, also in quadruple determination) were subtracted from all values. Furthermore, RM-A test samples [polyurethane film with $0.1 \%$ zinc diethyldithiocarbamate (ZDEC) (Hatano Research Institute, Food and Drug Safety Center, Hadano, Japan) were used as positive 

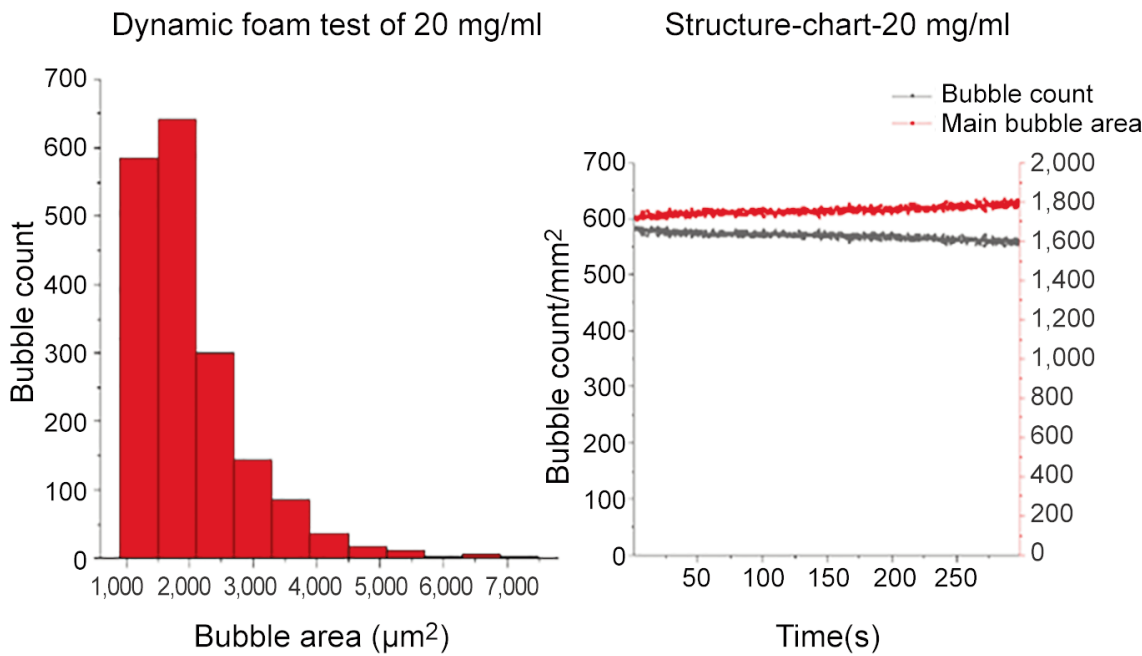

Figure 4. Bubble counts and distribution. The main fraction of the collagen foam has a bubble area of 1,000 to 2,000 $\mu m^{2}$, which is equivalent to an average diameter of about 36 to $50 \mu \mathrm{m}$.

control materials. As negative control, grade 4 titanium plates were incubated under the above-described extraction conditions.

Statistics. An analysis of variance (ANOVA), which enabled comparison of the data from the study groups via the GraphPad Prism 8.0 software (GraphPad Software Inc., La Jolla, CA, USA) was conducted for statistical analysis. Statistical differences were designated as significant if the $p$-values were less than 0.05 $\left({ }^{*} p \leq 0.05\right)$, and highly significant if the $p$-values were less than 0.01 $(* * p \leq 0.01)$ or less than $0.001(* * * p \leq 0.001)$. Finally, the data are shown as mean \pm standard deviation.

\section{Results}

Results of the ex vivo measurements. DFA bubble structure and distribution depending on collagen density.

The number of bubbles and the size distribution of the collagen foam bubbles were analyzed via DFA and shown in Figure 4. The left panel shows the real-time images of the bubbles within the foams. The green dots show the relative uniform sizes of the produced foam. Projection areas of the most foam bubbles were measured between $1000 \mu \mathrm{m}^{2}$ and $2000 \mu \mathrm{m}^{2}$, indicating diameters ranging from $46 \mu \mathrm{m}$ to 94 $\mu \mathrm{m}$. The largest bubble population had 28-48 $\mu \mathrm{m}$ diameter $(20 \mathrm{mg} / \mathrm{ml})$. The black line and red line for bubble count and mean bubble area, depending on time, showed the relatively high stability and uniformity of the prepared foam.

Results of the in vitro measurements. According to ISO 10993-5:2009, non-toxic ranges are defined for values $>70 \%$ of the blank sample for BrdU and XTT assays and for values $<130 \%$ of the blank sample for LDH assays. The collagen foam showed satisfactory biocompatibility in both concentrations tested (Figure 5). Thereby, a significant difference $(p \leq 0.001)$ compared to the positive control was shown in all three assays. In the BrdU and XTT assays, only a minor significant difference $(p \leq 0.01)$ compared to the negative control was measured at the concentration of 10 $\mathrm{mg} / \mathrm{ml}$. At the concentration of $30 \mathrm{mg} / \mathrm{ml}$, however, there was no significant difference compared to the negative control. Similar results were obtained from the LDH assay, where no significant difference between the negative control and the collagen foam with a concentration of $30 \mathrm{mg} / \mathrm{ml}$ was detected. Instead, there was a significantly greater difference $(p \leq 0.001)$ between the negative control and the collagen foam with a concentration of $10 \mathrm{mg} / \mathrm{ml}$. The results of Cerabone ${ }^{\circledR}$ and Jason ${ }^{\circledR}$ membrane should also be mentioned. While the Jason ${ }^{\circledR}$ membrane reached the areas defined as non-toxic in all three assays carried out and therefore, demonstrated convincing biocompatibility, Cerabone ${ }^{\circledR}$ reached the required limit values in BrdU and XTT assay, but showed an increase in the LDH assay, which is clearly in the cytotoxic range and even exceeds the value of the positive control, suggesting possible deficits in biocompatibility. In addition, the noticeably low value of the Jason ${ }^{\circledR}$ membrane in the LDH assay has to be considered.

\section{Discussion}

Collagen-based biomaterials are an essential element for soft tissue management with special focus on wound care. For example, collagen materials are frequently used for acute and chronic wounds as well as burns after surgical interventions $(15,16,19,20)$. The advantage of collagen is based on its proliferation-, differentiation- and adhesionpromoting properties, which favor early vascularization and therefore rapid tissue regeneration $(1,4,9)$. In addition, 


\section{A}

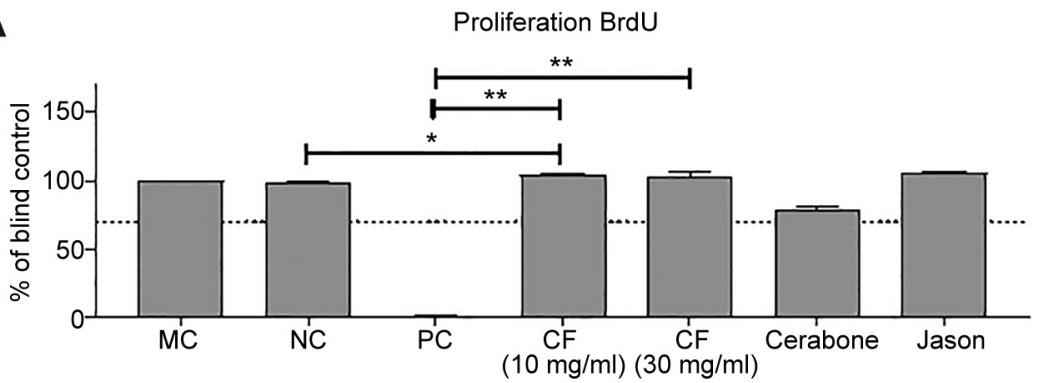

B

Viability XTT

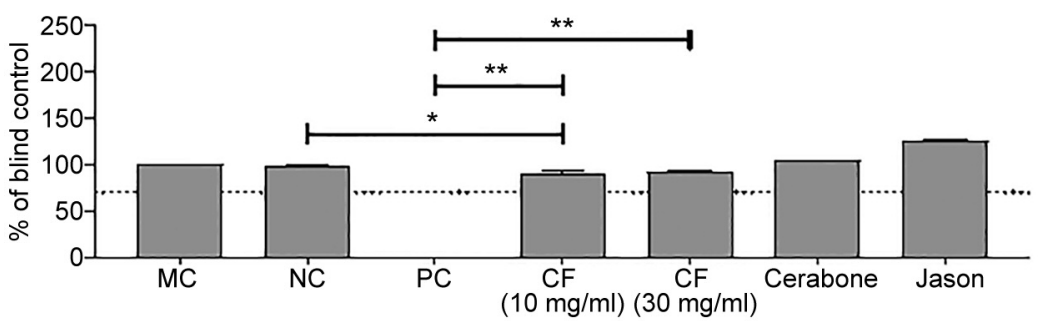

C

Toxicity LDH

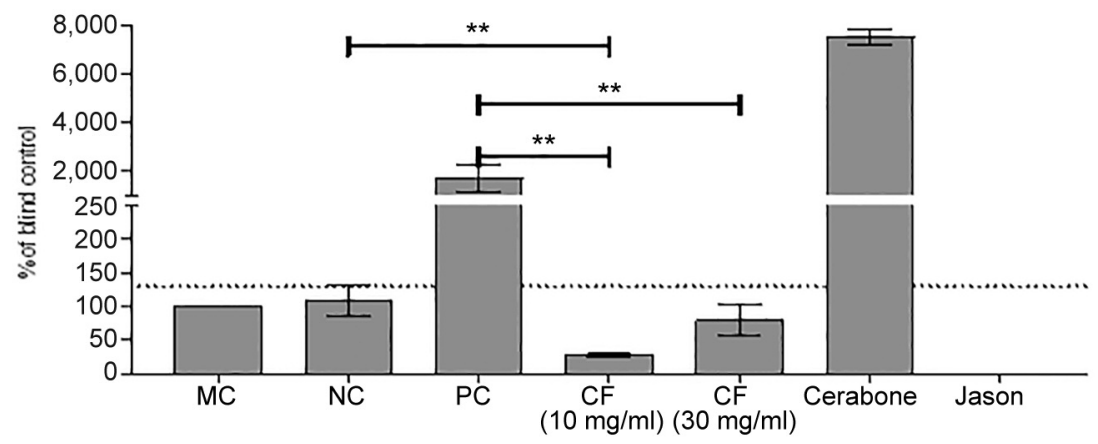

Figure 5. BCytocompatibility results using L929 cells in the different assays. (A) proliferation measured by BrdU assay; (B) viability measured by the Sodium 3,3'-[1(phenylamino)carbonyl]-3,4-tetrazolium]-3is(4-methoxy-6-nitro) Benzene Sulfonic acid Hydrate (XTT)-assay; (C) cytotoxicity measured by the Lactate Dehydrogenase ( $L D H)$ assay. Values were normalized against blind control. Means with error bars indicate standard deviations. Dotted line indicates thresholds which should not be exceeded (LDH) or undershot (XTT, BrdU). Significant differences are declared $\left({ }^{*} \leq \leq 0.01,{ }^{* *} p \leq 0.001\right) . M C$ : Medium control; NC: negative control (titanium grade 4); PC: positive control; CF: collagen foam.

collagen-based biomaterials are able to absorb liquids many times of their own weight and bind reactive oxygen as well as nitrogen species, which could also interfere with tissue regeneration $(41,42)$.

Until today, biomaterials for soft tissue regeneration like wound foams consist mainly of polyurethanes, hydro fibers or mixtures of these two materials, which absorb wound exudate in large volumes and thereby, create favorable conditions for wound healing $(43,44)$. Depending on the manufacturer, some foam dressings are additionally coated with silicone layers, which fixate the foam in the wound bed. Furthermore, foam dressings provide thermal isolation and protect the wound from bacteria and infections $(43,44)$. Another favorable advantage of current foams is their ability to completely fill out the wound beds, which reduces the remaining dead space for bacterial colonization and possible infections (45-47).

However, current available foam dressings also feature some disadvantages. Due to their strong fluid-absorbing properties, they are suitable for use on moderately to severely exudative wounds, but are contraindicated $e . g$., for use in very dry or necrotic wound areas (47). Most foams can be left on the wound bed for up to a week before they need to be removed (48). However, with removal there is always the risk of additional shear stress to the already agitated lesion, especially if newly formed tissue has already grown into the foam. The same applies to patients with very sensitive skin and the use of additional fixations for the foam 
dressings, which have to be removed with change of the dressing and thus can damage the newly formed tissue.

By using collagen as the basic material for a new type of wound foam, it could be possible to combine the regeneration-promoting properties of collagen with the advantages of a flexible foam, being able to adapt to any size and volume of the wound bed. A major advantage would be the ability to integrate the collagen directly into the wound bed as part of the newly formed ECM, which could make subsequent removal unnecessary and constantly supports tissue regeneration. Furthermore, by adjusting the liquid content of the foam, a moistening environment can be achieved for special indications like dry wounds. Therefore, the aim of the present study was to examine the macro- and micro-structure of an innovative collagen foam ex vivo and to investigate its cytocompatibility in vitro according to DIN ISO 10993. This new foam dressing could address and improve wound management for a broad range of applications.

First of all, the structure of the newly created collagen foam with a final concentration of $20 \mathrm{mg} / \mathrm{ml}$ was examined ex vivo using FIB-cryo-SEM and DFA. It could be shown that the bubbles in the foam were mainly uniform in diameter $(\sim 36-50 \mu \mathrm{m})$ and area $\left(\sim 1,000-2,000 \mu \mathrm{m}^{2}\right)$ and also distributed homogeneously within the foam $\left(\sim 600 / \mathrm{mm}^{2}\right)$. Furthermore, the number and size of the bubbles remained constant over the total observation period of $5 \mathrm{~min}$. These results suggest that the process used to produce the collagen foam can create a uniform microstructure within it. Collagen, as a natural component of human ECM, has binding sites for adhesion of fibroblasts, macrophages and epithelial cells, which is utilized in the creation of wound sponges or scaffolds in 3D-printing, both with defined pore sizes (49, 50). It is assumed that a constant pore size between 100-200 $\mu \mathrm{m}$ is optimal to enable the surrounding cells to proliferate and adhere to the surrounding porous structure $(49,50)$. These observations suggest that collagen foams should also provide this ideal pore size and distribution, with additional beneficial effect on tissue regeneration. In reference to our own measured values for the projection area and diameter of the bubbles formed, we assume similar advantageous attributes for enabling the foam to have a positive effect on the adhesion and ingrowth of the surrounding connective tissue cells. These possibilities should be further addressed in future studies. Furthermore, bubble size seems to decrease with an increasing viscosity of the foam. Since a higher viscosity could ensure a better hold within the wound and thus make the use of additional fixation systems redundant, it is important to carry out further investigations addressing more closely with the above-mentioned hypotheses.

In vitro, the foam showed sufficient cytocompatibility in all colorimetric assays for both tested concentrations. It could be shown that there were no significant differences to the negative control for the higher concentration $(30 \mathrm{mg} / \mathrm{ml})$, while mild significant differences $(p \leq 0.05)$ to the negative control were found for the lower concentration $(20 \mathrm{mg} / \mathrm{ml})$, which, however, appear to be negligible. The results of the reference materials for soft and hard tissue regeneration, Cerabone ${ }^{\circledR}$ and Jason ${ }^{\circledR}$ membrane, showed both good biocompatibility in the BrdU and XTT assays. However, unusual values were measured for both materials in the LDH assay. While the Jason ${ }^{\circledR}$ membrane did not seem to produce evaluable values in the assay, Cerabone ${ }^{\circledR}$ showed values that are even above the positive control and thus suggest clearly cytotoxic reactions. This might be explained by soluble nontoxic components of the materials, which interfere with the LDH assay. This can be prevented in the future by testing the materials with and without cells by subsequent subtraction of the values without cells from the values with cells as already shown by Jung et al. (51).

The results obtained for the collagen foam in the present study are congruent with previous observations, revealing that collagen, as natural and ubiquitous component of ECM, shows little to no damaging effects on the surrounding tissue, thus having sufficient biocompatibility $(17,52,53)$. However, additional in vitro assays could be used in order to analyze the properties and regenerative qualities of the foam in an even more differentiated manner. For example, it would be possible to further survey the differentiation processes of stem cells or primary cell lines that are potentially induced by the foam (54, 55). In addition, quantitative and qualitative measurement of the release of pro- or anti-inflammatory cytokines by immunologically active cell lines would give additional information about inflammation processes in the presence of the collagen foam. Nevertheless, the presented in vitro results require future in vivo investigations in order to analyze tissue reactions of the foam using histological, histomorphometrical and immunohistochemical assays. In this context, additional loading of the foam, e.g., with silver nanoparticles or plateletrich plasma (PRP), could be an interesting approach. The noticeable values of the reference materials in the LDH assay could be explained by the high sensitivity of the assay, which could be also considered as possible reason for the high values shown for Cerabone ${ }^{\circledR}$. Another reason for this measurement value can be found in the high release of calcium and phosphate ions, which might have a slight cytotoxic effect, even in case of the used static cell culture plates. This material has manifoldly been proved to be biocompatible in both preclinical and clinical studies, so that is it assumable that the ion release might not interfere with the bone healing process in in vivo situations due to the implant bed vascularization and the related tissue perfusion.

Altogether, the present study shows satisfactory in vitro compatibility of the newly developed collagen foams. The analysis of the microstructure reveals the effectiveness of the manufacturing process to create a homogeneous microstructure 
of the foam with mostly consistent bubble size and diameter. Taken together, these results suggest that collagen foams show the potential to be a promising new biomaterial for tissue regeneration, especially for wounds. Future additional studies, particularly addressing tissue responses in vivo, are required to emphasize the present results.

\section{Conflicts of Interest}

The Authors declare no conflicts of interest in relation to this study.

\section{Authors' Contributions}

Conceptualization, O.J., M.B. and X.X.; methodology, O.J., M.B. and X.X.; software, X.X.; validation, O.J. and M.B.; formal analysis, O.J and S.P.; Preparation of collagen foams and mixture with BSM, C.F.Z and F.K.; the DFA analysis and data calculation, C.F.Z and F.K.; investigation, O.J. and M.B.; resources, O.J. and M.B.; data curation, S.P.; writing-original draft preparation, O.J. and S.P..; writing-review and editing, M.B and X.X..; visualization, S.P.; supervision, O.J. and M.B.; project administration, O.J., M.B. and X.X.; funding acquisition, O.J., M.B. and R.K.

\section{Acknowledgements}

This work was supported by the Federal Ministry for Economic Affairs and Energy (BMWI-FKZ: ZF4289210AW8).

\section{References}

1 Wang X, Wang G, Liu L and Zhang D: The mechanism of a chitosan-collagen composite film used as biomaterial support for MC3T3-E1 cell differentiation. Sci Rep 6: 39322, 2016. PMID: 28000715. DOI: 10.1038/srep39322

2 Kozłowska J and Sionkowska A: Effects of different crosslinking methods on the properties of collagen-calcium phosphate composite materials. Int J Biol Macromol 74: 397-403, 2015. PMID: 25542169. DOI: 10.1016/j.ijbiomac.2014.12.023

3 Gordon MK and Hahn RA: Collagens. Cell Tissue Res 339(1): $247-$ 257, 2010. PMID: 19693541. DOI: 10.1007/s00441-009-0844-4

4 Mousavi S, Khoshfetrat AB, Khatami N, Ahmadian M and Rahbarghazi R: Comparative study of collagen and gelatin in chitosan-based hydrogels for effective wound dressing: Physical properties and fibroblastic cell behavior. Biochem Biophys Res Commun 518(4): 625-631, 2019. PMID: 31447120. DOI: 10.1016/j.bbrc.2019.08.102

5 Aslan B, Guler S, Tevlek A and Aydin HM: Evaluation of collagen foam, poly(l-lactic acid) nanofiber mesh, and decellularized matrices for corneal regeneration. J Biomed Mater Res B Appl Biomater 106(6): 2157-2168, 2018. PMID: 29024376. DOI: $10.1002 / j b m . b .34022$

6 Sionkowska A: Modification of collagen films by ultraviolet irradiation. Polymer Degradation and Stability 68(2): 147-151, 2020. DOI: $10.1016 /$ S0141-3910(99)00176-7

7 Usha R, Sreeram KJ and Rajaram A: Stabilization of collagen with EDC/NHS in the presence of L-lysine: a comprehensive study. Colloids Surf B Biointerfaces 90: 83-90, 2012. PMID: 22019452. DOI: $10.1016 /$ j.colsurfb.2011.10.002
8 Chau DY, Collighan RJ, Verderio EA, Addy VL and Griffin M: The cellular response to transglutaminase-cross-linked collagen. Biomaterials 26(33): 6518-6529, 2005. PMID: 15927250. DOI: 10.1016/j.biomaterials.2005.04.017

9 Cai Z and Yang G: Bacterial cellulose/collagen composite: Characterization and first evaluation of cytocompatibility. J Appl Polymer Sci 120: 2938-2944, 2011. DOI: 10.1002/app.33318

10 McPherson JM: The utility of collagen-based vehicles in delivery of growth factors for hard and soft tissue wound repair. Clin Mater 9(3-4): 225-234, 1992. PMID: 10149973. DOI: 10.1016/0267-6605(92)90103-z

11 Nakamura R, Katsuno T, Kitamura M, Yamashita M, Tsuji T, Suzuki R, Kishimoto Y, Suehiro A, Tateya I, Nakamura T and Omori K: Collagen sponge scaffolds containing growth factors for the functional regeneration of tracheal epithelium. J Tissue Eng Regen Med 13(5): 835-845, 2019. PMID: 30808067. DOI: $10.1002 /$ term. 2835

12 Alarcon EI, Udekwu K, Skog M, Pacioni NL, Stamplecoskie KG, González-Béjar M, Polisetti N, Wickham A, RichterDahlfors A, Griffith M and Scaiano JC: The biocompatibility and antibacterial properties of collagen-stabilized, photochemically prepared silver nanoparticles. Biomaterials 33(19): 4947-4956, 2012. PMID: 22494887. DOI: 10.1016/ j.biomaterials.2012.03.033

$13 \mathrm{Li} \mathrm{R}, \mathrm{Xu} \mathrm{Z}$, Jiang Q, Zheng Y, Chen Z and Chen X: Characterization and biological evaluation of a novel silver nanoparticle-loaded collagen-chitosan dressing. Regen Biomater 7(4): 371-380, 2020. PMID: 32793382. DOI: 10.1093/rb/ rbaa008

14 Sionkowska A, Skopinska-Wisniewska J, Gawron M, Kozlowska $\mathrm{J}$ and Planecka A: Chemical and thermal cross-linking of collagen and elastin hydrolysates. Int J Biol Macromol 47(4): 570-577, 2010. PMID: 20713081. DOI: 10.1016/j.ijbiomac. 2010.08.004

15 Pallaske F, Pallaske A, Herklotz K and Boese-Landgraf J: The significance of collagen dressings in wound management: a review. J Wound Care 27(10): 692-702, 2018. PMID: 30332361. DOI: $10.12968 /$ jowc.2018.27.10.692

16 Bunyaratavej P and Wang HL: Collagen membranes: a review. J Periodontol 72(2): 215-229, 2001. PMID: 11288796. DOI: 10.1902/jop.2001.72.2.215

17 Chattopadhyay S and Raines RT: Review collagen-based biomaterials for wound healing. Biopolymers 101(8): 821-833, 2014. PMID: 24633807. DOI: 10.1002/bip.22486

18 Avila Rodríguez MI, Rodríguez Barroso LG and Sánchez ML: Collagen: A review on its sources and potential cosmetic applications. J Cosmet Dermatol 17(1): 20-26, 2018. PMID: 29144022. DOI: 10.1111 jocd.12450

19 Moura LI, Dias AM, Carvalho E and de Sousa HC: Recent advances on the development of wound dressings for diabetic foot ulcer treatment - a review. Acta Biomater 9(7): 7093-7114, 2013. PMID: 23542233. DOI: 10.1016/j.actbio.2013.03.033

20 Bagheri Miyab K, Alipoor E, Vaghardoost R, Saberi Isfeedvajani M, Yaseri M, Djafarian K and Hosseinzadeh-Attar MJ: The effect of a hydrolyzed collagen-based supplement on wound healing in patients with burn: A randomized double-blind pilot clinical trial. Burns 46(1): 156-163, 2020. PMID: 31859087. DOI: 10.1016/j.burns.2019.02.015

21 Yoon D, Cho YS, Joo SY, Seo CH and Cho YS: A clinical trial with a novel collagen dermal substitute for wound healing in 
burn patients. Biomater Sci 8(3): 823-829, 2020. PMID 31782425. DOI: $10.1039 / \mathrm{c} 9 \mathrm{bm} 01209 \mathrm{e}$

$22 \mathrm{Ng} \mathrm{KW}$, Khor HL and Hutmacher DW: In vitro characterization of natural and synthetic dermal matrices cultured with human dermal fibroblasts. Biomaterials 25(14): 2807-2818, 2004. PMID: 14962559. DOI: 10.1016/j.biomaterials.2003.09.058

23 Ghanaati S, Kovács A, Barbeck M, Lorenz J, Teiler A, Sadeghi N, Kirkpatrick CJ and Sader R: Bilayered, non-cross-linked collagen matrix for regeneration of facial defects after skin cancer removal: a new perspective for biomaterial-based tissue reconstruction. J Cell Commun Signal 10(1): 3-15, 2016. PMID: 26660939. DOI: 10.1007/s12079-015-0313-7

24 Jung O, Radenkovic M, Stojanović S, Lindner C, Batinic M, Görke O, Pissarek J, Pröhl A, Najman S and Barbeck M: In Vitro and In Vivo biocompatibility analysis of a new transparent collagen-based wound membrane for tissue regeneration in different clinical indications. In Vivo 34(5): 2287-2295, 2020. PMID: 32871752. DOI: 10.21873/invivo.12040

25 Farndale RW, Sixma JJ, Barnes MJ and de Groot PG: The role of collagen in thrombosis and hemostasis. J Thromb Haemost 2(4): 561-573, 2004. PMID: 15102010. DOI: 10.1111/j.15387836.2004.00665.x

26 Kawamoto Y and Kaibara M: Procoagulant activity of collagen. Effect of difference in type and structure of collagen. Biochim Biophys Acta 1035(3): 361-368, 1990. PMID: 2207130. DOI: 10.1016/0304-4165(90)90101-2

27 Barbeck M, Kühnel L, Witte F, Pissarek J, Precht C, Xiong X, Krastev R, Wegner N, Walther F and Jung O: Degradation, bone regeneration and tissue response of an innovative volume stable magnesium-supported gbr/gtr barrier membrane. Int J Mol Sci 21(9): 3098, 2020. PMID: 32353983. DOI: 10.3390/ ijms 21093098

28 Lee SW and Kim SG: Membranes for the guided bone regeneration. Maxillofac Plast Reconstr Surg 36(6): 239-246, 2014. PMID: 27489841. DOI: 10.14402/jkamprs.2014.36.6.239

$29 \mathrm{Tal} \mathrm{H}$, Moses O, Kozlovsky A and Nemcovsky C: Bioresorbable collagen membranes for guided bone regeneration. Bone Regeneration, 2016. DOI: 10.5772/34667

30 Griffin JW, Hogan MV, Chhabra AB and Deal DN: Peripheral nerve repair and reconstruction. J Bone Joint Surg Am 95(23): 2144-2151, 2013. PMID: 24306702. DOI: 10.2106/JBJS L.00704

31 Lin MY, Manzano G and Gupta R: Nerve allografts and conduits in peripheral nerve repair. Hand Clin 29(3): 331-348, 2013. PMID: 23895714. DOI: 10.1016/j.hcl.2013.04.003

32 Zhang F, Xie Y, Celik H, Akkus O, Bernacki SH and King MW: Engineering small-caliber vascular grafts from collagen filaments and nanofibers with comparable mechanical properties to native vessels. Biofabrication 11(3): 035020, 2019. PMID: 30943452. DOI: $10.1088 / 1758-5090 / \mathrm{ab} 15 \mathrm{ce}$

33 Leal BBJ, Wakabayashi N, Oyama K, Kamiya H, Braghirolli DI and Pranke P: Vascular tissue engineering: Polymers and methodologies for small caliber vascular grafts. Front Cardiovasc Med 7: 592361, 2021. PMID: 33585576. DOI: $10.3389 / \mathrm{fcvm} .2020 .592361$

34 Yeo M, Lee JS, Chun W and Kim GH: An innovative collagenbased cell-printing method for obtaining human adipose stem cell-laden structures consisting of core-sheath structures for tissue engineering. Biomacromolecules 17(4): 1365-1375, 2016. PMID: 26998966. DOI: 10.1021/acs.biomac.5b01764
35 Lee HJ, Kim YB, Ahn SH, Lee JS, Jang CH, Yoon H, Chun W and Kim GH: A new approach for fabricating collagen/ECMbased bioinks using preosteoblasts and human adipose stem cells. Adv Healthc Mater 4(9): 1359-1368, 2015. PMID: 25874573. DOI: 10.1002/adhm.201500193

36 Lee V, Singh G, Trasatti JP, Bjornsson C, Xu X, Tran TN, Yoo SS, Dai G and Karande P: Design and fabrication of human skin by three-dimensional bioprinting. Tissue Eng Part C Methods 20(6): 473-484, 2014. PMID: 24188635. DOI: 10.1089/ten. TEC.2013.0335

37 Koch L, Kuhn S, Sorg H, Gruene M, Schlie S, Gaebel R, Polchow B, Reimers K, Stoelting S, Ma N, Vogt PM, Steinhoff $\mathrm{G}$ and Chichkov B: Laser printing of skin cells and human stem cells. Tissue Eng Part C Methods 16(5): 847-854, 2010. PMID: 19883209. DOI: 10.1089/ten.TEC.2009.0397

38 Ferreira AM, Gentile P, Chiono V and Ciardelli G: Collagen for bone tissue regeneration. Acta Biomater 8(9): 3191-3200, 2012. PMID: 22705634. DOI: 10.1016/j.actbio.2012.06.014

39 Jung O, Smeets R, Hartjen P, Schnettler R, Feyerabend F, Klein $\mathrm{M}$, Wegner $\mathrm{N}$, Walther $\mathrm{F}$, Stangier $\mathrm{D}$, Henningsen $\mathrm{A}$, Rendenbach C, Heiland M, Barbeck M and Kopp A: Improved in vitro test procedure for full assessment of the cytocompatibility of degradable magnesium based on ISO 10993-5/-12. Int J Mol Sci 20(2): 255, 2019. PMID: 30634646. DOI: $10.3390 / \mathrm{ijms} 20020255$

40 Steigmann L, Jung O, Kieferle W, Stojanovic S, Proehl A, Görke $\mathrm{O}$, Emmert S, Najman S, Barbeck $\mathrm{M}$ and Rothamel D: Biocompatibility and immune response of a newly developed volume-stable magnesium-based barrier membrane in combination with a PVD coating for guided bone regeneration (GBR). Biomedicines 8(12): 636, 2020. PMID: 33419327. DOI: 10.3390/biomedicines8120636

41 Metzmacher I, Ruth P, Abel M and Friess W: In vitro binding of matrix metalloproteinase-2 (MMP-2), MMP-9, and bacterial collagenase on collagenous wound dressings. Wound Repair Regen 15(4): 549-555, 2007. PMID: 17650099. DOI: 10.1111/ j.1524-475X.2007.00263.X

42 Schönfelder U, Abel M, Wiegand C, Klemm D, Elsner P and Hipler UC: Influence of selected wound dressings on PMN elastase in chronic wound fluid and their antioxidative potential in vitro. Biomaterials 26(33): 6664-6673, 2005. PMID: 15978664. DOI: 10.1016/j.biomaterials.2005.04.030

43 Chaganti P, Gordon I, Chao JH and Zehtabchi S: A systematic review of foam dressings for partial thickness burns. Am J Emerg Med 37(6): 1184-1190, 2019. PMID: 31000315. DOI: 10.1016/j.ajem.2019.04.014

44 Stoica AE, Chircov C and Grumezescu AM: Nanomaterials for wound dressings: an up-to-date overview. Molecules 25(11): 2699, 2020. PMID: 32532089. DOI: 10.3390/molecules 25112699

45 Hilton JR, Williams DT, Beuker B, Miller DR and Harding KG: Wound dressings in diabetic foot disease. Clin Infect Dis 39 Suppl 2: S100-S103, 2004. PMID: 15306987. DOI: 10.1086/ 383270

46 Jeffcoate WJ, Price P, Harding KG and International Working Group on Wound Healing and Treatments for People with Diabetic Foot Ulcers: Wound healing and treatments for people with diabetic foot ulcers. Diabetes Metab Res Rev 20(Suppl 1): S78-S89, 2004. PMID: 15150819. DOI: 10.1002/ dmrr.476 
47 Weller CD, Team V and Sussman G: First-line interactive wound dressing update: A comprehensive review of the evidence. Front Pharmacol 11: 155, 2020. PMID: 32180720. DOI: 10.3389/ fphar.2020.00155

48 O'Meara S and Martyn-St James M: Foam dressings for venous leg ulcers. Cochrane Database Syst Rev (5): CD009907, 2013. PMID: 23728697. DOI: 10.1002/14651858.CD009907.pub2

49 Janik $\mathrm{H}$ and Marzec $\mathrm{M}$ : A review: fabrication of porous polyurethane scaffolds. Mater Sci Eng C Mater Biol Appl 48: 586-591, 2015. PMID: 25579961. DOI: 10.1016/j.msec. 2014.12.037

50 Song X, Zhu C, Fan D, Mi Y, Li X, Fu RZ, Duan Z, Wang Y and Feng RR: A Novel human-like collagen hydrogel scaffold with porous structure and sponge-like properties. Polymers (Basel) 9(12): 638, 2017. PMID: 30966005. DOI: 10.3390/ polym9120638

51 Jung O, Smeets R, Porchetta D, Kopp A, Ptock C, Müller U, Heiland M, Schwade M, Behr B, Kröger N, Kluwe L, Hanken $\mathrm{H}$ and Hartjen P: Optimized in vitro procedure for assessing the cytocompatibility of magnesium-based biomaterials. Acta Biomater 23: 354-363, 2015. PMID: 26073090. DOI: 10.1016/ j.actbio.2015.06.005

52 Jung O, Radenkovic M, StojanoviĆ S, Lindner C, Batinic M, Görke O, Pissarek J, Pröhl A, Najman S and Barbeck M: In Vitro and In Vivo biocompatibility analysis of a new transparent collagen-based wound membrane for tissue regeneration in different clinical indications. In Vivo 34(5): 2287-2295, 2020. PMID: 32871752. DOI: 10.21873/invivo.12040
53 Gueldenpfennig T, Houshmand A, Najman S, Stojanovic S, Korzinskas T, Smeets R, Gosau M, Pissarek J, Emmert S, Jung $\mathrm{O}$ and Barbeck M: The condensation of collagen leads to an extended standing time and a decreased pro-inflammatory tissue response to a newly developed pericardium-based barrier membrane for guided bone regeneration. In Vivo 34(3): 9851000, 2020. PMID: 32354884. DOI: 10.21873/invivo.11867

54 Ahmed U, Ahmed R, Masoud MS, Tariq M, Ashfaq UA, Augustine R and Hasan A: Stem cells based in vitro models: trends and prospects in biomaterials cytotoxicity studies. Biomed Mater 16(4): 042003, 2021. PMID: 33686970. DOI: 10.1088/ 1748-605X/abe6d8

55 Jablonská E, Horkavcová D, Rohanová D and Brauer DS: A review of in vitro cell culture testing methods for bioactive glasses and other biomaterials for hard tissue regeneration. J Mater Chem B 8(48): 10941-10953, 2020. DOI: 10.1039/ d0tb01493a
Received March 19, 2021

Revised June 18, 2021

Accepted June 23, 2021 